\title{
Komunikasi Politik Megawati Dalam Membangun \\ Brand Image Partai
}

\author{
Jofanny Budiman, H.H. Daniel Tamburian \\ jofanny.915150053@stu.untar.ac.id,danielt@fikom.untar.ac.id
}

Fakultas Ilmu Komunikasi Universitas Tarumanagara

\begin{abstract}
PDIP or Partai Demokrasi Indonesia Perjuangan (Indonesian Democratic Party of Struggle) is one of the political parties that plays an important role in developing of the political situation in Indonesia. One of the figures who played an important role as a speaker and initiator from PDIP is Megawati Soekarnoputri. Where communication is one of the aspect and also an important factor in delivering political messages within a political party. This research aims to determine Megawati's political communication in building PDIP's brand image, where Megawati is the general chairman of PDIP and also plays an important role as the face of this political party. This type of research is a qualitative study and using a case study method. The theories used in this research include political science, political communication, political parties and also brand image. The results of this research indicate that Megawati Soekarnoputri is a firm and democratic figure in conveying political messages. The conclusions of this research indicate that Megawati Soekarnoputri's political communication as a party leader was good enough in building a brand image of PDIP.
\end{abstract}

Keywords: Political Communication, Brand Image, Megawati, PDIP

\begin{abstract}
Abstrak
PDIP atau Partai Demokrasi Indonesia Perjuangan merupakan salah satu partai politik yang berperan penting dalam kemajuan dunia politik di Indonesia. Salah satu tokoh yang berperan penting sebagai juru bicara dan penggagas PDIP adalah Megawati Soekarnoputri. Komunikasi menjadi salah satu aspek dan juga faktor penting dalam penyampaian pesan politik di dalam suatu partai politik. Penelitian ini bertujuan untuk mengetahui komunikasi politik Megawati dalam membangun brand image PDIP, sebagai Ketua Umum PDIP yang juga berperan penting sebagai wajah dari partai politik ini. Jenis penelitian ini merupakan penelitian kualitatif dengan menggunakan metode studi kasus. Konsep yang digunakan dalam penelitian ini, diantaranya seperti ilmu politik, komunikasi politik, partai politik dan juga brand image. Hasil penelitian ini menunjukkan bahwa Megawati Soekarnoputri merupakan sosok yang tegas dan demokratis dalam menyampaikan pesan politik. Kesimpulan dari penelitian ini menunjukkan bahwa komunikasi politik yang dilakukan oleh Megawati Soekarnoputri selaku pemimpin partai cukup baik dalam membangun brand image dari PDIP.
\end{abstract}

Kata Kunci: Komunikasi Politik, Brand Image, Megawati, PDIP

\section{Pendahuluan}

Sebagai ilmu mandiri, komunikasi berkaitan dan berpengaruh dengan banyak aspek kehidupan manusia. Komunikasi itu sendiri ialah upaya yang sistematis untuk merumuskan secara tegas asas-asas penyampaian informasi serta pembentukan pendapat dan juga sikap (Effendy, 2013). Salah satu aspek yang banyak diteliti dan dikaji dalam bidang komunikasi adalah politik dan juga dinamikanya. Komunikasi politik sangat penting diterapkan demi perkembangan demokrasi negara yang lebih 
baik, terutama bagi negara berkembang seperti Indonesia. Dimana komunikasi politik itu sendiri ialah komunikasi yang diarahkan kepada pencapaian suatu pengaruh, sehingga masalah yang dibahas oleh kegiatan komunikasi ini dapat mengikat semua warganya dengan sanksi yang ditentukan bersama melalui lembaga politik (Mukarom, 2016).

Komunikasi politik tidak hanya membahas mengenai lembaga pemerintahan legislatif dan eksekutif saja, melainkan juga partai politik. Secara umum, partai politik merupakan suatu kelompok dimana setiap anggotanya mempunyai orientasi, nilai-nilai dan cita-cita yang sama (Budiardjo, 2008).

Salah satu partai politik Indonesia yang sudah berdiri sejak lama adalah Partai Demokrasi Indonesia Perjuangan atau biasa yang disingkat dengan PDIP. Sebelum menjadi PDIP, partai yang diawali dengan nama PDI ini sudah berdiri sejak tahun 1973 dan masih terus berkembang hingga sekarang sebagai PDIP yang dipimpin oleh Ibu Megawati Soekarnoputri sebagai salah satu partai terkemuka di Indonesia.

Berdasarkan hasil survei Kompas pada kategori kelompok partai politik, pada 21 Maret hingga 1 April 2018 yang dilakukan dengan tatap muka terhadap 1.200 responden, elektabilitas PDIP masih berada dipuncak dan lalu diikuti oleh Gerindra dan juga Golkar. Elektabilitas PDIP mencapai persentase sebesar 33,3 persen, Gerindra 10,9 persen dan Golkar relatif konsisten pada 7 hingga 9 persen (Kompas.com, 2018).

Terpilihnya suatu partai politik untuk menduduki posisi tertinggi juga bergantung kepada para komunikator dari masing-masing partai politik. Dimana para komunikator politik harus bisa memberikan informasi dan juga pesan-pesan politik kepada publik, yang dapat membuat publik percaya bahwa partai politik tersebut lah yang terbaik.

Penelitian terdahulu yang berjudul "Representasi Kampanye Politik Dalam Game (Analisis Semiotik Dalam Game Jokowi Go! Dan Game Prabowo The Asian Tiger)" mengungkapkan bahwa segala pesan dan infromasi yang memiliki unsur atau muatan politik termasuk ke dalam pesan politik. Pidato politik, undang-undang pemilu, pernyataan politik, iklan politik, dan propaganda politik adalah contoh dari komunikasi yang mengandung pesan politik.

Megawati Soekarnoputri sebagai seorang pemimpin PDIP menjadi salah satu juru bicara atau komunikator politik kepada publik mengenai partai politik yang dipimpin olehnya. Segala perkataan dan informasi yang diucapkan dan diberikan oleh beliau kepada publik dan masyarakat, dapat membantu membangun citra atau brand image dari PDIP. Citra merek atau brand image ini sangat dipengaruhi oleh keputusan masyarakat atau konsumen. Pengertian citra merek atau brand image menurut Keller (1993) ialah bahwa suatu citra merek atau brand image merupakan konsep yang berasal dari alasan subyektif dan emosi pribadi konsumen, dimana persepsi tentang suatu merek merupakan refleksi dan asosiasi konsumen atas merek tersebut, (Ferrinadewi, 2008). Oleh karena itu, informasi maupun pemberitaan komunikasi politik yang diberikan oleh komunikator politik, dapat mempengaruhi persepsi masyarakat, bahwa apakah citra merek dari suatu partai politik dapat dianggap baik atau tidak.

Berdasarkan latar belakang di atas maka dilakukan penelitian untuk mengetahui gambaran mengenai komunikasi politik Megawati, khususnya seperti bagaimana komunikasi politik Megawati Soekarnoputri dalam membangun brand image PDIP? Penelitian ini dilakukan untuk mengetahui komunikasi politik Ibu Megawati Soekarnoputri selaku Ketua Umum PDIP dalam membangun brand image PDIP, 
untuk mengetahui pesan-pesan politik seperti apa yang disampaikan Megawati kepada pengurus atau kader PDIP dan masyarakat Indonesia dan juga untuk mengetahui bagaimana Megawati merespon setiap pesan-pesan politik yang merugikan PDIP atau merusak nama baik PDIP. Penelitian ini dilakukan di Kantor Dewan Pimpinan Pusat PDI Perjuangan di Jakarta Pusat dengan orang-orang terdekat dari Megawati.

\section{Metode Penelitian}

Pada penelitian ini, penulis menggunakan jenis penelitian kualitatif, dimana penelitian kualitatif ini merupakan penelitian untuk memahami fenomena tentang apa yang dialami oleh subjek penelitian, misalnya seperti perilaku, persepsi, tindakan dan motivasi, secara holistic, dengan cara deskripsi dalam bentuk kata-kata dan juga bahasa, pada suatu konteks khusus dengan memanfaatkan berbagai macam metode alamiah (Moleong, 2009).

Peneliti menggunakan jenis penelitian kualitatif ini dikarenakan peneliti akan mencari jawaban dari suatu masalah dan peristiwa yang ada yang tak dapat dihitung dengan angka, sehingga dapat menemukan makna dan informasi yang lebih mendalam.

Metode penelitian yang digunakan di dalam penelitian ini adalah studi kasus. Studi kasus biasanya dimunculkan karena keinginan seorang peneliti untuk memecahkan satu masalah tertentu. Peneliti harus meneliti bagaimana perkembangan diri subjek, penyebab, perilaku keseharian, dan alasan serta bagaimana perilaku berubah dan penyebab terjadinya perubahan perilaku tersebut (Idrus, 2009). Studi kasus digunakan sebagai metode penelitian dikarenakan ingin mencari dan mengetahui serta mengumpulkan informasi lebih mendalam pada kasus dan juga permasalahan yang ada.

Pada penelitian ini, pengumpulan data dilakukan dengan menggunakan berbagai macam cara seperti wawancara, observasi, studi kepustakaan dan juga dengan penelusuran data online. Subyek dalam penelitian ini adalah Sekretariat PDIP dan juga kerabat yang sangat dekat dengan Megawati serta pihak-pihak yang bekerja dan terkait dari PDIP. Sedangkan obyek dalam penelitian ini adalah komunikasi politik yang biasanya digunakan oleh Megawati dalam membangun citra PDIP.

Teknik analisis data yang digunakan dalam penelitian ini adalah teknik analisis data dalam model interaktif menurut Huberman dan Miles, yang dibagi menjadi tiga hal utama, yaitu reduksi data, penyajian data, dan juga penarikan kesimpulan atau verifikasi. Sedangkan teknik keabsahan data yang digunakan adalah dengan menggunakan teknik triangulasi. Triangulasi sendiri merupakan teknik pemeriksaan data, di mana teknik ini memanfaatkan sesuatu yang lain. Diluar data tersebut, untuk keperluan pengecekan atau sebagai pembanding data itu. Teknik triangulasi yang paling banyak digunakan adalah pemeriksaan melalui sumber lainnya (Moleong, 2009). Dalam penelitian ini digunakan dua teknik triangulasi, yaitu triangulasi metode dan triangulasi sumber data.

\section{Hasil Temuan dan Diskusi}

Hasil temuan dan diskusi dari penelitian ini akan dibagi ke dalam konsep pembahasan yang akan dijelaskan sebagai berikut: 
Komunikasi dan Pesan Politik Megawati

Dalam hal ini, terdapat komunikasi dan juga pesan politik yang biasanya disampaikan oleh Megawati kepada para anggota partai. Komunikasi yang dilakukan oleh Megawati di dalam partai adalah komunikasi yang bersifat tegas dan juga konsisten. Selain itu Megawati selaku pemimpin partai juga menanamkan komunikasi yang mengarah kepada keterbukaan atas kesempatan-kesempatan yang juga diberikan kepada para anggota partai atau kader dan jajarannya untuk mengemukakan pendapat. Selain komunikasi politik, adapula beberapa pesan-pesan politik yang sering disampaikan berulang kali oleh Megawati untuk mengingatkan kepada para anggota partai. Pesan-pesan yang seringkali disampaikan seperti untuk selalu bekerja demi kepentingan rakyat, untuk menyambangi rakyat, karena tanpa rakyat, suatu partai politik bukanlah apa-apa.

Gambar 1. Artikel Megawati di dalam media pemberitaan online Kompas.com

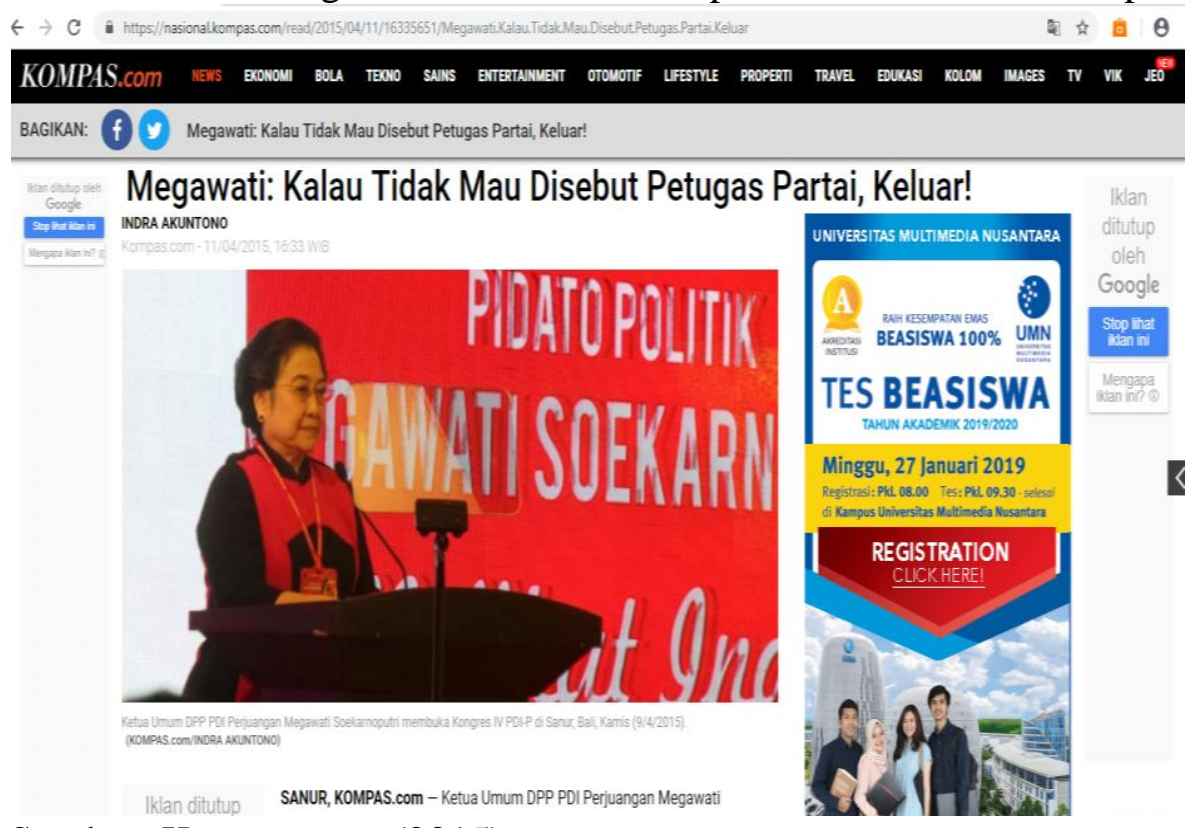

Sumber: Kompas.com (2015)

Selain itu pesan yang disampaikan lainnya oleh Megawati adalah seperti untuk tidak mencuri uang negara, apabila hal tersebut terjadi maka anggota partai yang melakukan hal tersebut akan langsung dipecat. Hal ini sama dengan berita yang pernah diberitakan dan dipublikasikan oleh Kompas.com, menjelaskan bahwa anggota partai merupakan petugas partai dan seluruh kebijakan yang dilakukan harus berpihak kepada kepentingan rakyat, apabila tidak demikian maka harus keluar dari partai, maka inilah yang menjadikan Megawati sebagai sosok yang tegas dalam melakukan komunikasi dengan seluruh anggota partai.

\section{Partai Politik di Indonesia}

Secara umum dapat dikatakan bahwa partai politik adalah suatu kelompok terorganisir dimana setiap anggota kelompok mepunyai orientasi, nilai-nilai, dan citacita yang sama. Tujuan dari kelompok ini ialah untuk memperoleh kekuasaan dan merebut kedudukan politik, biasanya dengan menggunakan cara konstitusional untuk melaksanakan programnya (Budiardjo, 2008). Dimana partai politik merupakan 
tempat asal mula dan awal lahirnya para pemimpin bangsa untuk membuat bangsa ini lebih maju dan lebih baik di kemudian hari.

Partai Politik di Indonesia saat ini sedang memasuki dan mengalami masa-masa riskan dimana akan diadakannya Pemilu 2019. Masa-masa riskan ini adalah dimana mulai banyak bermunculan berita hoax yang tidak sesuai dengan data dan keadaan di partai politik yang sebenarnya. Dalam hal ini, Megawati selaku pemimpin partai PDI Perjuangan, lebih mengarahkan para anggota partai untuk lebih menghiraukan dan tidak merespon hal-hal negatif yang dapat merugikan partai. Beliau lebih mengarahkan para anggota partai untuk menangkis hal tersebut dengan menunjukkan hasil kerja untuk kepentingan rakyat. Hal ini dilakukan untuk mencapai cita-cita partai yang tentunya baik juga di mata masyarakat, dan juga untuk mencapai tujuan utama partai dalam menyambangi rakyat Indonesia untuk kedepannya.

\section{Sosok Megawati Dalam Membangun Brand Image PDIP}

Seperti menurut Keller (1993), brand image adalah persepsi tentang merek yang merupakan refleksi konsumen akan asosiasinya pada merek tersebut (Ferrinadewi, 2008). Dalam hal ini brand image berarti dimana persepsi yang ada masyarakat, tergantung kepada apa yang dilakukan oleh suatu partai politik. Brand Image suatu partai politik sangat dipengaruhi oleh persepsi masyarakat mengenai baik atau tidaknya partai politik tersebut.

Di dalam suatu partai politik, pasti dan akan selalu ada terjadinya factor-faktor negatif dari luar yang ingin membuat buruk nama suatu partai politik tersebut. Berdasarkan hasil wawancara yang dilakukan oleh peneliti dengan narasumber, terdapat beberapa informasi yang didapatkan mengenai tanggapan Megawati Soekarnoputri terhadap hal-hal negatif yang tersebar untuk menjatuhkan nama baik partai. Informasi yang didapatkan adalah mengenai bagaimana cara Megawati mempertahankan citra atau brand image partai yang selama ini sudah ada dan terbentuk juga di dalam persepsi masyarakat Indonesia.

Megawati selaku pimpinan selalu mempimpin dengan tegas, mengatakan kepada para anggota partai dan kadernya untuk selalu mengumpulkan seluruh anggota partai untuk rapat koordinasi, membahas pekerjaan-pekerjaan yang perlu dilakukan demi kesejahteraan masyarakat.

Lalu kegiatan lainnya yang dilakukan guna untuk mendukung kemajuan partai juga dengan cara melakukan rekrutmen kader untuk bekerja di partai. Di PDIP sendiri terdapat sekolah partai yang dapat memberikan Pendidikan mengenai dunia politik terutama partai politik bagi generasi muda maupun orang-orang yang memiliki minat dan semangat untuk terjun ke dalam dunia partai politik dan bekerja untuk menyambangi masyarakat bersama.

Hal ini juga didukung dengan berita dan juga artikel yang ada di beberapa media pemberitaan online yang memiliki keterkaitan dengan kepemimpinan Megawati di dalam PDIP. Dimana di dalam artikel media pemberitaan ini memberitakan bahwa sudah entah berapa kali Megawati dan juga PDIP di-bully, namun survey partai politik yang tertinggi masih dipegang oleh PDIP "Saya enggak tahu juga (kenapa tertinggi), tapi ternyata memang rakyat yang menentukan," 
Gambar 2. Artikel Megawati di dalam media pemberitaan online Viva.com

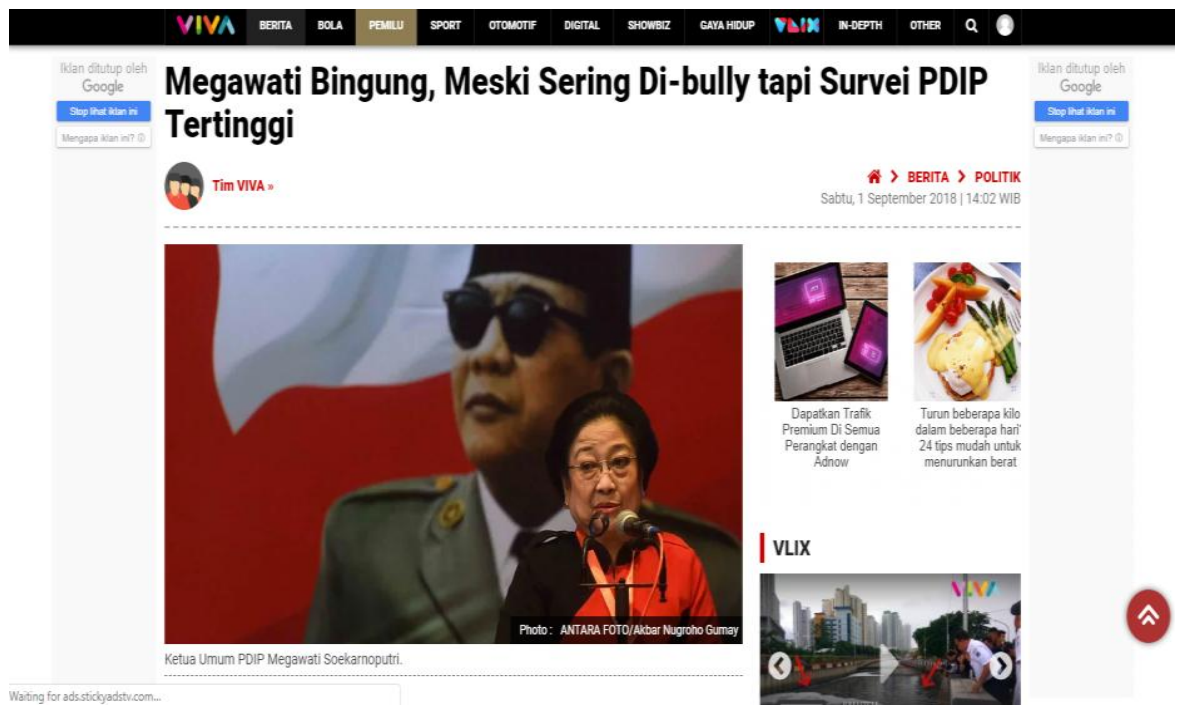

Sumber: Viva.com (2018)

Artikel berita di atas menjelaskan bahwa walaupun Megawati maupun partai politiknya yaitu PDIP sering di-bully atau kritik oleh pihak lain, namun berdasarkan hasil survei, PDIP tetap menjadi partai dengan hasil survei tertinggi.

Gambar 3. Artikel Megawati di dalam media pemberitaan online Kompas.com

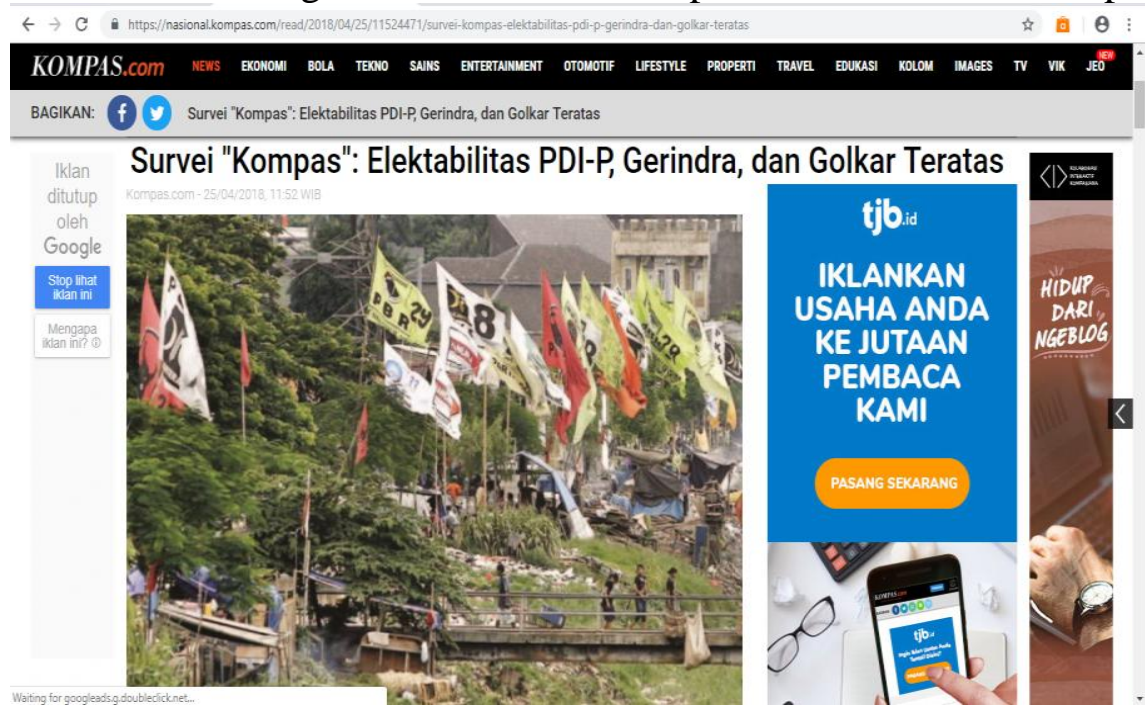

Sumber: Kompas.com (2018)

"Elektabilitas PDI-P mencapai 33,3 persen. Angka ini sedikit naik dibandingkan dengan survei pada Oktober 2017" Berdasarkan media pemberitaan di atas, penulis membandingkan jawaban dan pernyataan narasumber dengan berita yang ada. Dalam hal ini, yang dinyatakan oleh narasumber dan yang tertera pada media berita dapat dikatakan kurang lebih sama, dimana sosok Megawati sangat berpengaruh sekali dalam terus membentuk dan membangun brand image PDIP. Survei tertinggi yang dipegang oleh PDIP juga menbuktikan bahwa masyarakat masih mempercayai partai politik tersebut, karena masyarakat juga berperan besar dalam kemajuan partai 
politik. Walaupun dicerca dan didatangi hal-hal negatif dari pihak lain, Megawati tetap memimpin partai secara demokratis tanpa memikirkan hal tersebut.

\section{Simpulan}

Komunikasi politik yang dilakukan oleh Megawati sudah cukup baik, dalam arti dapat memberikan pesan-pesan politik yang tegas, yang dapat selalu diingat oleh para anggota partai, kader dan jajarannya, seperti selalu mengingatkan agar para anggota partai dan jajarannya tidak terlibat hal-hal tidak baik, seperti mencuri uang rakyat. Lalu Megawati juga selalu bersikap secara demokratis dalam mengambil keputusan pada saat rapat partai, demi kepentingan dan kesejahteraan masyarakat bersama.

Partai politik di Indonesia saat ini masih dalam keadaan yang belum stabil, dimana hoax dan berita bohong masih tersebar untuk merusak nama baik partai. Megawai selaku pimpinan Partai Demokrasi Indonesia Perjuangan (PDIP), lebih mengambil sikap yang tidak membalas dan tidak responsif akan hal tersebut. Megawati lebih memilih untuk membalas berita hoax tersebut dengan kerja untuk rakyat, demi kepentingan untuk menyambangi rakyat dan membiarkan waktu yang akan menjawab.

Selama kurang lebih 45 tahun PDI berdiri, hingga sekarang ini menjadi PDI Perjuangan, Megawati selalu menjadi sosok yang sangat berpengaruh bagi kemajuan citra PDIP. Megawati selalu memberitahukan kepada para anggota partai, kader dan jajarannya untuk selalu mempersiapkan rekrutmen kader untuk bekerja di dalam partai, dan juga rapat-rapat koordinasi untuk membahas kerja-kerja untuk rakyat. Hal ini dilakukan demi untuk menjaga nama baik PDIP yang sudah terbentuk di kalangan masyarakat. Dan berdasarkan hasil penelitian dan wawancara dengan narasumber, menurut mereka, para anggota partai dan kader partai, Megawati merupakan sosok pemimpin yang sangat berpengaruh demi kemajuan PDIP.

\section{Ucapan Terima Kasih}

Ucapan terima kasih penulis sampaikan kepada seluruh narasumber yang telah bersedia meluangkan waktu untuk melakukan wawancara dan memberikan informasi kepada penulis selama proses pengumpulan data untuk penelitian ini. Penulis juga ingin mengucapkan terima kasih kepada seluruh pihak yang bersangkutan dalam penelitian ini dan juga Fakultas Ilmu Komunikasi Universitas Tarumanagara.

\section{Daftar Pustaka}

Akuntono, Indra. (2015). Megawati: Kalau Tidak Mau Disebut Petugas Partai, Keluar!. $11 \quad$ April 2015. https://nasional.kompas.com/read/2015/04/11/16335651/Megawati.Kalau.Tid ak.Mau.Disebut.Petugas.Partai.Keluar

Budiardjo, Miriam. (2008). Dasar-dasar Ilmu Politik. Jakarta: PT Gramedia Pustaka Effendy, Onong Uchjana. (2013). Ilmu Komunikasi Teori dan Praktek. Bandung: PT Remaja Rosdakarya

Ferrinadewi, Erna. (2008). Merek dan Psikologi Konsumen. Yogyakarta: Graha Ilmu

Gatra, Sandro. (2018, April 25). Survei "Kompas": Elektabilitas PDI-P, Gerindra, dan Golkar Teratas. 25 April 2018. 
Halim, J., \& Widayatmoko, W. (2015). Representasi Kampanye Politik Dalam Game (Analisis Semiotik Dalam Game Jokowi Go! Dan Game Prabowo The Asian Tiger). Jurnal Komunikasi, 7(1), 98-107. Retrieved from https://journal.untar.ac.id/index.php/komunikasi/article/view/10/31

Idrus, M. (2009). Metode Penelitian Ilmu Sosial. Yogyakarta: PT. Gelora Aksara Pratama

Moleong, Lexy J. (2009). Metodologi Penelitian Kualitatif. Bandung: PT Remaja Rosdakarya

Mukarom, H.Zaenal. (2016). Komunikasi Politik. Bandung: CV Pustaka Setia

Viva.com. (2018). Megawati Bingung, Meski Sering Di-bully tapi Survei PDIP Tertinggi. https://www.viva.co.id/berita/politik/1070660-megawati-bingungmeski-sering-di-bully-tapi-survei-pdip-tertinggi

https://nasional.kompas.com/read/2018/04/25/11524471/survei-kompas-elektabilitaspdi-p-gerindra-dan-golkar-teratas 